\title{
Effect of Dual Role Conflict (Work Family Conflict, Workload and Job Stress) on the Performance of Employees of PT Bank Negara Indonesia (Persero) Tbk Pare-pare
}

\author{
Nurdjanah Hamid ${ }^{1}$, Wahda $^{2}$, and Samsinar ${ }^{3}$ \\ \{nununghamid17@gmail.com ${ }^{1}$, iwarasjid@gmail.com ${ }^{2}$, samsinar@yahoo.co.id ${ }^{3}$ \} \\ Universitas Hasanuddin, Makassar, Indonesia ${ }^{1,2,3}$
}

\begin{abstract}
The aim of this research is to determine the impact of multiple role conflicts, such as work-family, workload, and work stress, on the performance of female staffs at PT. Bank Negara Indonesia (Persero) in Pare-pare. The data collected in this study is quantitative and qualitative and were analyzed by using path analysis. This study demonstrates that both multiple role conflicts and workload directly affected workrelated stress on the female employees. The correlation between the two variables suggests that increase in workload is directly aligned to the work stress of female employees. Moreover, direct work stress influences the female employees' performance negatively which means as the work stress increases, the performance would decrease.
\end{abstract}

Keywords: Multiple roles, workload, employee performance.

\section{Introduction}

Dual roles have become a phenomenon in the world of work that we often encounter, with not a few women are participating in the industrial world. The contribution of women in economic development can be seen from the tendency of women's participation in the workforce. As one indicator, participation in the economy is shown in the rate of increase in women's participation in the workforce.

The existence of globalization that occurs results in intense competition at work, this competition does not only include men, but also women began to flock to enliven this work competition. This illustrates that the world of work now really provides fierce competition that must be responded by prospective employees with qualities that are in accordance with what is desired by the company that will be his or her goal [1].

It can be seen that the boundaries between women and men in work are increasingly eroded due to technological growth, and women who are aware of the importance of education choose to study as high as possible. With high education, of course, women choose to become a career woman. It was further explained that working in the perspective of women in addition to earning money and also in addition to the economy was also related to the awareness of the position of women both in the family and society that requires them to strengthen their abilities and empower themselves to work [2]. 
The phenomenon of many women working is to earn extra income as well as to express themselves in the midst of family and community [1]. The demands to work for Indonesian women are not solely caused by demands for meeting the needs of the household but are also based on the desire to participate and get an appreciation for their struggles and achievements. However, no doubt, the main role of women who are married is taking care of the household.

A dual role becomes something that inevitably undergoes, which in turn is confronted with a conflict between his role in the family and the role in his career. Work-family conflict explains the conflict between work responsibilities at home and work in his career Frone \& Chopeer (1992) [3]. Employees who cannot divide or balance the time for family and work affairs can cause conflict, namely family-work conflict, or often called dual role conflict. Work-family conflict is one form of inter-role conflict where the role pressure is from work roles and family roles, and there are discrepancies between these roles in some respects. Three forms of dual role conflict namely; (a) time-based conflict, where time spent on one role makes it difficult for individuals to participate in another role. (b) strain-based conflict, this is consistent with fatigue or irritability dimensions, where fatigue or irritability in one role affects the performance of individuals in other roles. In other words, the role is incompatible due to fatigue or irritability caused by one role resulting in difficulties in fulfilling the demands of the other role. (c) behavior-based conflict, where the pattern of individual behavior in one role is not in line with expectations in other roles.

The dual role conflict and workload that occurs to an employee who has a dual role does not rule out the possibility that the employee will experience work stress. Every job can be said to be a cause of stress, because it is based on too much workload, role conflict, and the process of adjusting relationships with others. Stress that occurs at work is the result of emotional and physical reactions due to the failure of individuals to adapt in the work environment where there is a mismatch between expectations and reality. Job stress is a process that causes a person to feel sick, uncomfortable or tense due to work, workplace or certain work situations.

Past research carried out by Silviana et al (2016) [4], with the title Effect of Dual Role Conflict and work load on performance with work stress as an intervening variable on employees of PT Bank Mandiri (Persero) Tbk branch of Jember alun alun shows that partially conflicting dual roles has a positive effect and significant to work stress, work stress influence negatively and significantly on employee performance, dual role conflict has adversely and significantly affect the employee performance, dual role conflict has a negative and not significant impact on performance through employee work stress.

Based on the foregoing, this research seek to discover the effect of dual role conflict (work-family conflict, workload and work stress on the performance of the employees of PT Bank Negara Indonesia (Persero) for pare-pare branches. 


\subsection{Conceptual Framework}

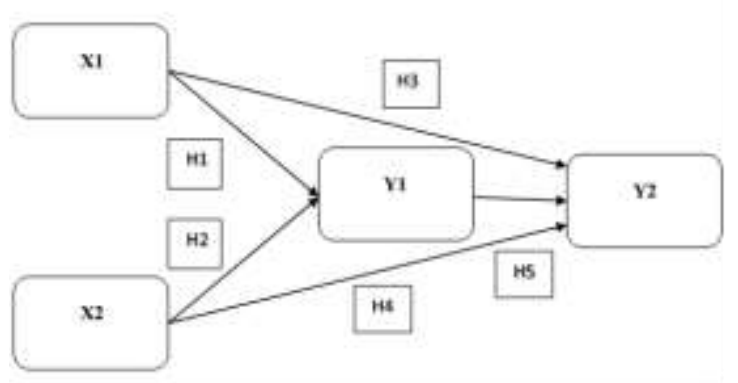

Fig. 1. Conceptual Framework

\section{Information:}

$\mathrm{X} 1=$ Dual-Role Conflict

$\mathrm{X} 2 \quad=$ Workload

$\mathrm{Y} 1=$ Work Stress

Y2 = Performance

H1 = Dual role conflict has a positive and significant effect on work strain for female employees

$\mathrm{H} 2=$ Workload positively and significantly influences the work strain of female employees

H3 = Dual role conflict has a negative and significant impact on the performance of female staff

$\mathrm{H} 4 \quad=$ Workload has a negative and significant effect on staff performance

H5 = Job strain has a negative and significant effect on the performance of staff

\section{$2 \quad$ Methodology}

The location of this research was carried out at the office of PT Bank Negara Indonesia (Persero) Tbk. The Parepare branch is located on Jl. Veterans, Ujung Sabbang, Parepare City. The population of this study is all employees of the office of PT Bank Negara Indonesia Branch of Parepare who are married, and the total of their children is 36 . Then the sample is drawn by a purposive sampling method so that the number of samples is 36 people.

\subsection{Method of collecting data}

Data collection was carried out using a closed type questionnaire, which consisted of a series of questions used to obtain data on several factors that formed the variable dual role conflict (work-family conflict), workload, and stress on the performance of PT Bank BNI (Persero) Tbk Parepare Branch.

\subsection{Data analysis technique}

Data collection in this research was carried out through questionnaires containing a number of statements along with a Likert scale answer form column with a range of 1-5. The data analysis technique was carried out using path analysis with the help of the SPSS 16.00 program 


\section{Women's Dual Role Conflict (Work Family Conflict)}

Frone, Rusell \& Cooper (1992) define conflicting dual roles as the inability of a person to balance work and family [3]. Boles et al in Dian (2008) Conflicting dual roles (work family conflicies) are conflicts that occur due to an imbalance of roles between responsibilities at the residence and at the workplace [5]. Job demands are related to pressures emanating from the workplace, such as work to be done in a hurry and dead line. Family demands relate to the time needed to handle household chores and look after children.

\subsection{Workload}

Kusnadi (2014) Workload is a condition that arises from the relationship between task demands, work environment, skills, behavior and employee perception of the work he does. From an ergonomic point of view, every workload received by a person must be appropriate and balanced with the physical and psychological abilities of the workers who receive the workload [6]. Workload can be in the form of physical workload and psychological workload.

Different point of view in defining workload. Webster put forward the workload as the amount of work or work time expected to workers and the total amount of work that must be completed by a department or group of workers in a certain period of time.

\subsection{Work stress}

Define work stress as a physical or psychological division of the normal human condition caused by stimuli from the work environment while defining work stress as a process that causes people to feel sick, uncomfortable, or tense due to work, workplace, or certain work situations.

Greenberg (2001) argues that work stress is an individual anxiety reaction that is caused by interactions between requirements in the environment and individual characteristics, and stress is the response or cause for early warning of excessive information in several aspects, and when stress occurs at work, it is called work pressure [7].

\subsection{Performance}

States that performance is the result of the quality and quantity of work attained by an employee in carrying out their duties commensurate with the responsibilities given to them.

Furthermore, Brahmasari and Suprayetno (2008) suggested that a person's performance is a measure of the degree to which a person's success in carrying out his work duties [8], whereas according to Motowidlo, Borman \& Smith (1997), performance is a set of organizational values of discrete behavior where the work results achieved by individuals exceed the standards within the specified time period [9]. 


\section{$4 \quad$ Result}

\subsection{Validity and Reliability Test}

Table 1. Validity and Reliability Test

\begin{tabular}{|c|c|c|c|c|}
\hline No & Variables/Indicators & r Count & $\begin{array}{c}\text { Cronbach's } \\
\text { Alpha }\end{array}$ & Description \\
\hline \multirow[t]{4}{*}{1.} & Dual Role Conflict (X1) & & 0.757 & Reliable \\
\hline & Dual Role Conflict 1 & 0.870 & & Valid \\
\hline & Dual Role Conflict 2 & 0.789 & & Valid \\
\hline & Dual Role Conflict 3 & 0.804 & & Valid \\
\hline \multirow[t]{3}{*}{2.} & Work Load (X2) & & 0.628 & Reliable \\
\hline & Work Load 1 & 0.882 & & Valid \\
\hline & Work Load 2 & 0.827 & & Valid \\
\hline \multirow[t]{5}{*}{3.} & Job Stress (Y1) & & 0.800 & Reliable \\
\hline & Job Stress 1 & 0.849 & & Valid \\
\hline & Job Stress 2 & 0.805 & & Valid \\
\hline & Job Stress 3 & 0.777 & & Valid \\
\hline & Job Stress 4 & 0.738 & & Valid \\
\hline \multirow[t]{5}{*}{4.} & Performance (Y2) & & 0.867 & Reliable \\
\hline & Performance 1 & 0.806 & & Valid \\
\hline & Performance 2 & 0.843 & & Valid \\
\hline & Performance 3 & 0.845 & & Valid \\
\hline & Performance 4 & 0.889 & & Valid \\
\hline
\end{tabular}

Source: Processed Data (2019)

Based on table 1 above related to the reliability test shows the Cronbach Alpha value> 0.60 so that it can conclude the four reliable variables, while based on the value of $r$ arithmetic of each indicator shows the value of $\mathrm{r}$ count $>\mathrm{t}$ table so that it can be concluded that all indicators that form the four variables are valid.

\subsection{Hypothesis Test}

Tabel 2. Hypothesis Test

\begin{tabular}{lccccc}
\hline & Path Coefficient & $\mathrm{t}$ count & $\mathrm{t}$ table & Sig & Information \\
\hline $\mathrm{X} 1$-> Y1 & 0.585 & 4.576 & 2.035 & 0.001 & Accepted \\
$\mathrm{X} 2$-> Y1 & 0.272 & 2.131 & 2.035 & 0.041 & Accepted \\
$\mathrm{X} 1$-> Y2 & -0.385 & -2.821 & 2.035 & 0.008 & Accepted \\
\hline
\end{tabular}




\begin{tabular}{|c|c|c|c|c|c|}
\hline $\mathrm{X} 2->\mathrm{Y} 2$ & -0.235 & -2.064 & 2.035 & 0.047 & Accepted \\
\hline $\mathrm{Y} 1$-> Y2 & -0.370 & -2.544 & 2.035 & 0.016 & Rejected \\
\hline
\end{tabular}

Source: Processed Data (2019)

\subsection{Dual Role Conflict contributed significantly to the work stress of female employees}

Based on the calculation above, it is known that the direct effect of Dual Role Conflict on work stress is 0.585 or $58.5 \%$ with a $t$ value $>t$ table value of $4.576>2.035$. This is also reinforced by a significance value of 0.001 , which is smaller than the 0.05 confidence level. This indicates that the alternative hypothesis (Ha) is accepted, meaning the Dual Role Conflict has a positive and significant effect on the Work Stress of PT Bank BNI (Persero) Tbk ParePare Branches. This is supported by several theories which state that undergoing two roles at the same time, as a worker as well as a housewife, is not easy. Female employees who are married and have children have heavier roles and responsibilities than single women. The dual role is experienced by the woman because besides having a role in the family, the woman also plays a role in her career. Employees who cannot divide or balance time for family and work affairs can lead to conflicts that are family conflicts and work conflicts, or often referred to as Dual Role Conflict women between family and work. Conditions like the above often trigger conflicts that occur in the life of the company; if not taken seriously will have a very significant impact on efforts to achieve company goals, one of which is the low overall employee performance will affect company productivity [10]. But not only that is caused by conflicts that are not handled appropriately and wisely, it can also have a direct impact on employees because they are in a state of awkward atmosphere that causes mental stress (stress). This is also explained [1] that task demands are a source of work stress where things that include task demands are the amount of work that must be done. As for the factors that affect stress such as: excess Work Load, responsibility for others, career development, lack of group cohesion, inadequate group support, organizational structure and climate, areas within the organization, task characteristics, and the influence of Ivancevich and Matteson (1990) leaders [11]. In addition, the strength of the relationship or the correlation coefficient of 0.467 or $46.7 \%$ there is a positive relationship between Dual Role Conflict work stress of female employees. This shows that the higher the Dual Role Conflict, the higher the work stress of women at the University of Indonesia administration.

\subsection{Work Load is a significant contributor to the work stress for female employees}

Based on the calculation above, it is known that the direct effect of Work Load on Work stress is 0.272 or $27.2 \%$ with a calculated $t$ value $>t$ table value of $2.131>2.035$. This is also reinforced by the significance value of 0.041 , which is smaller than the 0.05 confidence level. This indicates that the alternative hypothesis (Ha) is accepted, meaning that Work Load has a positive and significant effect on Work Stress of Employees of PT Bank BNI (Persero) Tbk Pare-Pare Branch. This is supported by Ahmad Ahid Mudayana's statement (2010) which explains that Job Stress high affect employees who hold a double on the work that is actually not part of the work (excessive work load), employees also become ineffective at doing work [12]. In addition [13] states that shifts or night work often causes fatigue for employees due to excessive work load that accumulates causing stress due to the inability of individuals to cope 
with excessive work load.The theory is supported by the findings of Aster Andriani Kusuma (2014) [14] showing that the Work Load variable has a positive effect on work stress with a t value of 49.553 greater than t table 1.96 and an estimated coefficient of 0.924 , the coefficient is a positive sign that when increasingly the higher the Work Load, the higher the work stress of PT. Apie Indo Karunia's employees in Sidoarjo Surabaya and the results of research from Denizia Rizky \& Tri Wulida Afrianty (2018) show the coefficient of the Work Load path towards the 34tres Work as 0.347 with the direction of a positive relationship [15], a significant direction meaningful that with the increase in Work Load will give rise to the Job Training at the East Java Provincial Office in Surabaya)

\subsection{Dual Role Conflict adversely and significantly affect the performance of female employees}

Based on the calculation above, it is known that the direct effect of Dual Role Conflict on Performance is -0.3385 or $-38.5 \%$ with a calculated t value <-t table value that is $-2.821<$ 2.036. With a significance value of 0.008 smaller than the 0.05 confidence level. This indicates that the alternative hypothesis ( $\mathrm{Ha}$ ) is accepted, which means the Dual Role Conflict has a negative and significant effect on the Performance of Staffs of PT Bank BNI (Persero) Tbk, the Pare-Pare Branch. Conflicts between family roles and work that have occurred can reduce role performance, reduce verbal communication, poor marital adjustment, and other negative impacts on mothers and fathers in careers. The impact of the Dual Role Conflict is not much different from the impact of the conflict mentioned earlier. But the impact of Dual Role Conflict does not only affect Performance as an employee of a company but also has an impact on daily life in the household because Dual Role Conflict certainly occurs in a woman who is married even has children. Someone who has a dual role has more than one role, namely as an employee, a wife and also as a mother. This is also supported by findings in research from Atik Diana Nasekhah (2016) [5]. The results of the study indicate that there is a negative influence between women's Dual Role Conflict on Performance shown by the significance value smaller than the 0.05 confidence level and the regression coefficient has a negative value of -0.491 shows that the negative effect has an impact on the declining Performance of female employees in LPP RRI Yogyakarta. And the results of research from Mega Silviana et al (2017) with the path coefficient of -0.318 so that the Dual Role Conflict affects the level of Performance of PT. Bank Mandiri (Persero) Tbk Branch employees Jember Square where the higher the level of Dual Role Conflict that occurs, the lower the performance of the employee [16].

\subsection{Work Load lead to an undesirably significant effect on employee performance}

Based on the calculation above, it is known that the direct effect of Work Load on Performance is -0.235 or $-23.5 \%$ with the calculated $t$ value $<\mathrm{t}$-table value that is $-2.064<-$ 2.036. With a significance value of 0.047 smaller than the 0.05 confidence level. This indicates that the alternative hypothesis $(\mathrm{Ha})$ is accepted meaning that Work Load has a negative and significant effect on the Performance of Staffs of PT Bank BNI (Persero) Tbk Branch of Pare-Pare. The findings in this study support the results of research from Sinta Monika (2017). there is a negative influence of Work Load on Employee Performance can be seen from $\mathrm{t}$ count $=-7.647<\mathrm{t}$ table $=-2.010$. Which means Work Load increases, employee performance will decrease at PT Glamedia Bandung Perkasa. And research from Aster Andriani Kusuma et al (2014) where the results of the study with the results of estimate 
coefficient of -0.60 so it was concluded that Work Load has a negative and significant effect on Performance at PT Apie Indo Karunia Job Stress has a negative and significant effect on the performance of female employees The direct effect of Job Stress on Performance is -0.370 or $-37.0 \%$ with the value of $\mathrm{t}$ count $<-\mathrm{t}$ table value that is $-2.544<-2.036$. This is also reinforced by the significance value of 0.016 smaller than the 0.05 confidence level. This indicates that the alternative hypothesis $(\mathrm{Ha})$ is accepted or Ho is rejected, it means that Work Stress has a negative and significant effect on the Performance of Employees of PT Bank BNI (Persero) Tbk. Pare-Pare Branch. The high is a drastic decline in employee performance. According to Ivancevich and Matteson (1980), the cause of stress is caused by the role of someone in undergoing a particular profession, especially jobs related to public services. This is also supported by research findings from Ria Puspita Sari (2015) where work stress variables negatively affect employee performance at Jambuluwuk Malioboro Boutique Hotel Yogyakarta with the results of the beta coefficient $(\beta-0.323(* \mathrm{p}<0.05)$ where target indicators and company expectations are not achieved, employees feel stressed due to not achieving Job target set o The impact of the company is declining employee performance [17]. As well as research from Ade Agus Diama Purwa Diaputra (2019) where the results of research with beta coefficients $(\beta-0.283)$, these results mean that Job Stress has a negative and significant effect on employee performance at PT Destination Asia Bali in Bali.

\subsection{Work stress has a negative and significant effect on the performance of female employees}

The direct effect of Job Stress on Performance is -0.370 or $-37.0 \%$ with the value of $t$ count <-t table ie $-2.544<-2.036$. This is also reinforced by the significance value of 0.016 smaller than the 0.05 confidence level. This indicates that the alternative hypothesis $(\mathrm{Ha})$ is accepted or Ho is rejected, it means that Work Stress has a negative and significant effect on the performance of personnels of PT Bank BNI (Persero) Tbk. Pare-Pare Branch, this is in line The negative impact of stress at the critical level is a decrease in employee performance drastically. According to Ivancevich and Matteson (1980), the stress is caused by the role someone undergoing in a particular profession, especially jobs related to public services. This is also supported by research findings from Ria Puspita Sari (2015) where work stress variables negatively affect the performance of Jambuluwuk Malioboro Boutique Hotel Yogyakarta employees with the results of the beta coefficient $(\beta-0.332(* \mathrm{p}<0.05)$ where the target indicators and company expectations are not achieved, the employees feel stressed due to not achieving job targets set by the company, the impact is declining employee performance [17]. The results of the study with beta coefficient values $(\beta-0.283$, these results have the meaning that work stress has a negative and significant effect on employee performance at PT Destination Asia Bali in Bali.

\section{Conclusion}

The level of Dual Role Conflict and Stress of female employees at PT Bank Negara Indonesia Pare Pare Branch is classified as high. While the level of workload and performance of female employees at PT. BNI (Persero) Tbk, the Pare-Pare branch is in the medium category. The highest Dual Role Conflict indicator is (Strain based conflict) while the Work Load indicator are Jobs which often requires the employees to do a lot of work. The highest 
work stress indicator is that the employees will lose their appetite if the burden the work is solid and the last Performance indicator is the indicator that there are still workloads that are often done not on time.

Dual Role Conflict directly has a significant effect on the work strain of female staffs of PT. Bank Negara Indonesia (Persero) Tbk. The correlation between Dual Role Conflict to work stress are positive which means that increasing Dual Role Conflict can increase the work strain of female staff of PT. Bank Negara Indonesia (Persero) Tbk Work Load directly has a significant effect on the work strain of female employees of PT. Bank Negara Indonesia (Persero) Tbk.

The correlation between work load on work stress are positive which means that increasing Work Load can increase the work strain of BNI female staffs. Dual Role Conflict directly has a negative effect on the performance of BNI female employees through work stress, meaning that when Dual Role Conflict increases, work stress will also increase, increased employee work stress will result in decreased female employee performance. Work Load directly has a negative effect on the performance of BNI female employees through work stress, meaning that when Work Load increases, work stress will also increase. Increased Job Stress for female employees will reduce the performance of female employees.

Job stress directly has a negative effect on the performance of female staffs of PT. Bank Negara Indonesia (Persero) Tbk which means that when work stress increases, Performance will decrease

The leaders and executives of PT Bank Negara Indonesia is advised to be sensitive to several things that can increase Dual Role Conflict experienced by female employees considering the enormous effect on decreasing Performance through work stress. This is based on the results of research showing that Dual Role Conflict felt by female employees including the high category is using the indicator of (Strain based conflict). Therefore there are several things that can be done by the leaders and executives to reduce the high Dual Role Conflict to be lower are to make policies that can facilitate the needs of female employees. Leaders must be sensitive to the conditions of work stress of female employees and suppress them as early as possible so that the work stress of female employees remains at the optimum level. This is consistent with the results of research that shows that work stress affects performance. Increased work stress can reduce the performance of female employees, thus leaders plan activities that can refresh the minds of employees. This can be done by holding sports activities together every week and holding gatherings once a year. With this program the activity is expected to reduce work stress even though the Dual Role Conflict and Work Load done increases.

\section{Reference}

[1] Robbins, Stephen P.: Essentials of Organizational Behavior (Terjemahan) Edisi Kelima, Penerbit Erlangga; Jakarta (2003)

[2] Sutrisno, Edy. : Manajemen Sumber Daya Manusia, Kencana Prenada Media Group; Jakarta (2016)

[3] Frone, Rusell and Cooper.: Antecedents and outcomes of work-family conflict: Testing a model of the work-family interface. Pp. 77:65-78 (1992)

[4] Silviana, M.: Pengaruh Dual Role Conflict dan Work Load terhadap Performance dengan Job Stress sebagai variabel intervening pada Karyawati PT Bank Mandiri (Persero) TBK Cabang Jember Alun-alun. Fakultas Ekonomi dan Bisnis, Universitas Jember (2017)

[5] Atik Diana Nasekhah.: Pengaruh Konflik Peran terhadap Performance Wanita karir Pada Universitas Sam Ratulangi Manado. Vol.2, pp. 450-456 Jurnal EMBA (2016) 
[6] Kusnadi, M. A. : Hubungan Antara Work Load Dan Self-Efficacy Dengan Stress Kerja Pada Dosen Universitas X. Fakultas Psikologi Universitas Surabaya (2014)

[7] Greenberg, J. and Robert A. Baron.: Behavior in Organization International Edition, New Jersey, Prentice Hall (2003)

[8] Brahmasari, Ida Ayu dan Agus Suprayetno.: Pengaruh Motivasi Kerja, Kepemimpinan, dan Budaya Organisasi Terhadap Kepuasan Kerja Karyawan serta Dampaknya pada Performance Perusahaan (Studi kasus pada PT. Pei Hei International Wiratama Indonesia). Vol. 10, pp. 124-135. (2008)

[9] Motowidlo, Borman \& Smith.: Expending the Criteria Domain to Include Elements of ExtraRole Performance. San Fransisco, Jossey-Bass (1997)

[10] Anoraga.: Psikologi Kerja. Rineka Cipta, Jakarta (1992)

[11] Ivancevich, J. M and Matteson, M. T.: Organizational Behavior and Management, McGraw Hill , New York (1990)

[12] Ahid Mudayana, Ahmad.: Pengaruh Motivasi dan Work Load Terhadap Performance Karyawan di Rumah Sakit Nur Hidayah Bantul. Vol. 4, pp. 76 - 143 (2010)

[13] Munandar, A.S.: Psikologi Industri dan Organisasi. Penerbit Universitas Indonesia, Jakarta (2001)

[14] Aster Andriani Kusuma dan Yoyok Soesatyo. Pengaruh Work Load dan Job Stress dan dampaknya terhadap Performance. Vol 2, (2014)

[15] Denizia R, Tri Wulida A.: Pengaruh Work Load terhadap Job Stress dengan work life balance sebagai variabel intervening (Studi pada Dinas Sosial Provinsi Jawa Timur Surabaya) Vol. 61. Jurnal Administrasi Bisnis (JAB) (2018)

[16] Mega Silfiana.: Pengaruh Dual Role Conflict dan Work Load Terhadap Performance Dengan Stress Kerja Sebagai Variabel Intervening pada Karyawati PT.Bank Mandiri (Persero) Tbk Cabang Jember Alun alun .Tesis Program Pascasarjana Universitas Jember ( UNEJ) (2016) 